Mr. Stewart added that he expected that the target of 20,000 graduates a year in pure or applied science set for about 1970 by the Barlow Committee would be met during 1965. Rather more than 25,000 boys and girls left school in the year 1962-63 with two or more passes in the Advanced Level Examination for the General Certificate of Education, at least one of which, and mostly all of which, were in science subjects.

\section{Land and Natural Resources}

IN a written answer in the House of Commons on January 19, the Prime Minister stated that the Minister of Land and Natural Resources would be responsible for research into the possibilities of conserving and aug. menting national water resources. Accordingly, the new Minister would assume responsibility for those aspects of the Minister of Housing and Local Government's work concerned with the Water Resources Board, including the uppointment of members and financial responsibility. He would take a leading part in any major projects, such as estuarial barrages, which involve co-ordination of various different interests in a particular river and with which a number of different Departments are concerned. $\mathrm{He}$ would also be responsible for plans for reorganizing the water supply industry under full public ownership. However, the Minister of Housing and Local Government would continue in England to exercise his statutory functions in relation to water supply and river management, particularly executive responsibility for questions of water distribution, minimum acceptable flow in rivers, abstractions, river pollution and sewerage. $\mathrm{He}$ would also share with the Secretary of State for Wales his existing statutory responsibilities for the appointment and functioning of river authorities, but the Minister of Land and Natural Resources would also be one of the Ministers who appoint those members of river authorities who are "qualified in respect of public water supply". Appropriate arrangements would be made between the three Ministers about future appointments to the three river authorities concerned with catchment areas in both Fngland and Wales, and these authorities would look to London or Cardiff as appropriate for the problem. The provisions of the Water Resources Act, 1963, were not as yet fully in effect and the position would be kept under review to see whether experience in implementing those provisions called for any change in these arrangements. The position in Scotland was unchanged. In a further answer on January 21 the Prime Minister added that details of the Minister's responsibilities for the establishment of a Land Commission and for future policy relating to the availability of land would be set out in a Transfer of Functions Order to be laid before the House.

\section{Scientific Advisory Panel to the Ministry of Agriculture, Fisheries and Food}

IN a written reply to a question in the House of Commons on January 21 concerning arrangements for securing advice on the scientific aspects of questions arising within the field of agriculture, fishories and food, Mr. F. Peart, Minister of Agriculture, Fisheries and Food, said that he had gone into this question following the retirement of Sir Harold Sanders from the post of chief scientific adviser (agriculture), and had decided to establish a Scientific Advisory Panel under the chairmanship of Prof. A. C. Frazer, of the University of Birmingham. This Panel would be available to advise him on the scientific aspects of any questions affecting the activities of his Department which might be referred to it. The Panel would also be free to offer its advice on any problems in this field whenever in its view this was desirable. The responsibilities of the heads of the scientific branches in the Ministry would not bo affected in any way by these new arrangements. On the other hand, it was hoped that the establishment of the Panel would lead to closer links between the universities and the Ministry.

\section{The World Weather Centre, Washington}

THE World Weather Centre in Washington commenced operation on January 1 and is now providing services on. request to all members of the World Meteorological Organization. Essentially it is concerned with gathering, processing and distributing weather observations. It will prepare weather analyses and forecasts for as much of the globe as possible. From the Centre, the processed weather information will be transmitted to regional and national meteorological centres. Opportunities will be provided for training meteorologists from member countries. The Centre will conduct both basic and applied research on large-scale weather problems, and will store weather information for research purposes. The planned activities of the Centre cannot as yet be fully implemented because weather data are not available over much of the Earth's oceanic areas. Moreover, the present meteorological satellite system does not as yet provide global satellite coverage. However, it is hoped that the Tiros Operational Satellite System, which is planned to be launched in about a year's time, will eliminate that deficiency. Plans are being developed to implement the Centre in progressive steps. The events leading to the establishment of the World Meteorological Centre began in 1960, when the first two Tiros weather satellites were successfully launched. Photographs taken by television cameras on board were used by the U.S. Department of Commerce Weather Bureau in improving analyses, forecasts and warnings. Washington and Moscow have already been designated as World Centres by the World Meteorological Organization, and a third centre in the southern hemisphere is envisaged.

\section{Annual Growth Rate in Britain}

IN the Westminster Bank Review for November 1964, an article by Prof. Alan Day, "The Myth of Four Per Cent Growth", estimates the present annual growth of capacity as 3.3 per cent, to which may be added an extra 0.2 per cent to be activated by a regional policy designed to make use of under-employed labour in the North. This suggests that, while the latter policy could also lead to greater inflationary pressures, since the upward trend in the ratio of rate of investment to gross national product appears to have levelled out since 1961 , the annual rise of productivity may become stabilized at about $2 \cdot 7$ per cent. Prof. Day also expects a slower rise in the labour force, but nevertheloss believes we could achieve a 4 per cent growth, including a big increase in the ratio of investment to national income, though at the price of a severe but temporary setback to the growth of present expenditure. Four per cent could serve a useful social purpose if treated as a target to be achieved only by sacrificing present consumption and severe disturbance to vested interests and economic and social rigidities.

\section{Careers in Biology}

SINCE the first edition of Biology as a Career appeared in 1953, there has been a steady expansion of biological science and a perceptibly growing recognition by the public of its value. The fourth edition is published under the conviction that there is now greater need than ever for a general guide describing the training, work and prospects of the professional biologist (Pp. 44. London: Institute of Biology, 1964. 3s. 6d.). In this booklet, the opportunity has been taken to bring facts up to date and to include a new appendix, indicating qualifications necessary for entry as well as giving brief details of the interests of the biological departments of British universities.

\section{Kindrogan Field Centre}

The Scottish Field Studies A.ssociation Field Centre in Garth Memorial Hostel was closed at the end of 1963 and a new, self-contained, residential field centre was opened in March 1964 at Kindrogan, a large country house stand- 